\title{
Polygyny, Bound Feet, and Perversion
}

Sympathie et sévérité. La relation père-fils dans la Chine médiévale

簡介: 〈一夫多妻, 纏足, 與 倒錯“Perversion”〉

\section{Keith McMahon}

\section{OpenEdition}

\section{Journals}

Édition électronique

URL : http://journals.openedition.org/extremeorient/215

DOI : 10.4000/extremeorient.215

ISSN : 2108-7105

Éditeur

Presses universitaires de Vincennes

Édition imprimée

Date de publication : 1 janvier 2012

Pagination : 159-188

ISSN : 0754-5010

Référence électronique

Keith McMahon, "Polygyny, Bound Feet, and Perversion », Extrême-Orient Extrême-Occident [En ligne], Hors-série | 2012, mis en ligne le 01 janvier 2015, consulté le 01 mai 2019. URL : http:// journals.openedition.org/extremeorient/215; DOI : 10.4000/extremeorient.215 


\title{
Polygyny, Bound Feet, and Perversion
}

\author{
Keith McMahon
}

The role of the father is both one in which he acts and others act for him. In one case, he conducts and commands. In the other, he is absent or stands back while others, women in particular, act on his behalf. Two key scenarios in Chinese history and literature illustrate wives and mothers acting on the father's behalf: polygyny and footbinding. In texts as far back as the Han dynasty (206 B.C.-220 A.D.), the supreme virtue in an emperor's wife and concubines was lack of jealousy. A virtuous empress harmonized relations between herself and the imperial concubines; she encouraged the emperor to take additional women, even introducing them to him. A similar situation occurred in the practice of footbinding, in which mothers undertook the binding of their daughters' feet, doing so by their own methods and on their own schedule. In households across China from the Song dynasty (960-1279) to the early Republic (1911-1920s), mothers initiated and managed the binding of their daughters' feet. The underlying link between polygyny and footbinding had to do with the logic in which women initiated and/or managed practices that involved their own subjection and self-mutilation. A key notion was the woman's supposedly freely willed acceptance, which is one of several signals indicating that a structure of perversion framed both polygyny and footbinding. What is perverse in this sense; and how can psychoanalytic theory and its definition of perversion throw light on the underlying link between polygyny and footbinding?

Perversion refers to situations in which subjects are compelled to freely accept conditions that are disadvantageous and even painful to them. The pervert is someone who engineers the situations that produce such behavior. In a classic example, he saves the victim from harm that he himself causes the victim. To say this metaphorically in terms of footbinding, the man compels the woman to mutilate her feet; she willingly perpetuates the mutilation, which becomes a standard by which she rises in value for the sake of marriage and concubinage, all in the service of the father-husband. Perversion is structural in nature, that is, it is a program with a set of roles to which subjects are invited and compelled 
to submit. At the head of the program is the figure of the perverse Master who pretends to be both the beneficiary and commander of his victims, whose agency he obfuscates and disavows. He marries several women at once, but expects them to be grateful to marry him and to co-exist unjealously. He marries the woman, but only on the condition that she weaken herself by binding her feet so that his role as Master can be further justified and enhanced. In what follows I will define polygamy, perversion, and footbinding separately, then together, all along keeping in mind that polygyny and footbinding did not necessarily overlap in actual practice. That is, most polygynists' wives had bound feet, but not all fathers and husbands of bound-footed women were polygynists. Another key point is that perversion was something that tinged and tainted polygamy and footbinding. Although it was structural and programmatic in nature, it was not the sole driver of these practices, nor did it describe each and every individual subject. It did not necessarily guarantee the results it desired, moreover, because subjects did not necessarily conform to its wishes in the way it expected.

If other articles in this issue discuss the father as patriarch and procreator, this one addresses the perverse male who is not necessarily a father in just those senses. Perversion in polygyny and footbinding is about the man in the primary sense of the male Master, in particular the one with multiple wives or the one with a bound-footed wife. The role of fathering children is almost superfluous in the discussion of polygynous perversion, except for the fact that being a polygynist is in a fundamental sense for the sake of fathering children, especially sons, to carry on the family line - thus the main moral justification of the institution of polygyny in pre-modern China. Similarly, in the case of footbinding, the focus is not primarily on the father but on the mother who manages the binding of her daughter's feet for the sake of making her daughter as marriageable as possible - thus the main reason for footbinding in pre-modern China. Both polygyny and footbinding are about situations that surround the role of the man as father. It is more convenient to contain the notion of father within the larger notion of the male Master, which includes all the various roles: Master, polygynist, husband, father, and son on his way to becoming these.

As for the notion of perversion, it has undergone wide use in recent years. There is in fact no agreed upon single definition of the term, which because of negative connotations has even been replaced by the term paraphilia in American psychiatry. Although I will occasionally borrow from the clinical context, I am mainly using perversion as a sexual political term with ideological implications. In general, two divergent usages exist, one which views perversion as positively disruptive of the heteronormative order, and the other, the one I am following, which takes perversion negatively as a disavowal of the lack inherent in the law of the Other. According to the first view, to reduce it to simplest terms, 
everyone is perverse, or should, so to speak, realize his or her perverse potential. Perversion is a stand-in for desire and its capacity to subvert established meaning, social hierarchy, and enforced identity. Perversion resists adaptation to the normative order. In the second view, all law, authority, and prohibitions are nothing but a grand deception, which perversion counters with its scene of exemption from the law except insofar as the pervert pretends to be the law's instrument. The latter pervert imagines a Law, with a capital "L," beyond law and authority, that is, possessing the inherent power to represent the object of desire and to satisfy desire. ${ }^{1} \mathrm{He}$ represents that Law, whether he views himself as ultimate embodiment of the superego or disguises the woman (or some other entity) as that embodiment for him. This second, Lacanian, sense of perversion is the one that I will elaborate below in terms of the link between polygyny and footbinding.

\section{The perverse polygynist}

Who then was the polygynously perverse subject? The evidence comes from both historical and literary sources. History provides the inherited notions of polygyny as institution, which justified polygyny and made it appear as though women's jealousy could be made to disappear. Literary evidence comes from male-authored fiction of the last few centuries of late imperial China, which portrayed women encouraging polygyny upon a passively accepting man. Some sources manifest perversion in its extreme, others only faintly, and still others resist and escape it. An example of a faintly tinged case of perversion occurs in the eighteenth-century novel, Dream of the Red Chamber (Honglou meng), in which the main male character, Jia Baoyu, enjoys floating among multiple female partners. He washes in water that girls have already used, bathes with maids, tussles with them or his female cousins, combs girls' hair and watches them do so, and helps them with their clothing. But he does not do these things in a sexually aggressive way, nor in a way that disavows the agency of the woman. In other words, Jia Baoyu in Dream of the Red Chamber is an example of someone who is not quite perverse but who points toward perversion. Eighteenth and nineteenth century sequels to Dream of the Red Chamber, however, portray a Baoyu who fully realizes his perverse potential. As a true pervert, he pretends he understands women, but in fact takes the appearance of understanding women as a way of gaining access to them. He constructs a polygynous scenario in which, for example, he takes innocent physical intimacy with girls as a direct route to

1. Regarding the divergent usages of perversion, see Nobus and Downing (2006). See also discussion from Teresa de Lauretis in footnote 10. 
educating them about sex and inducing them to line up as adoring lovers, wives, and concubines. The women not only adore him but become the agents and managers of polygyny, not its jealous participants. They allow and encourage the man to take other wives. They even set the limits on his enjoyment, which if it weren't for their efforts he would carry to excess. In short, he can thank them for coaxing and coddling him as he meanwhile enjoys harmonious sex with them all.

As literary examples, Dream of the Red Chamber and its sequels have a basis in the historical institution of polygyny. The core element of polygynous perversion was the disavowal of women's jealousy. In other words, the polygynist did not need to force women to comply. Instead, women would actively support polygyny; and it would be respectable women who would support it. As a polygamist, the man was the vehicle and instrument of something that was supposed to be. His central justification was the very institutionalization of polygyny, which promoted a system of order with rationales and recommendations for appropriate living styles. There were laws, rules, and principles, as well as customs and ideals of behavior. The polygamous institution's primary rationale was that a man must have sons to carry on the family line and must do so even if it meant taking secondary wives. This was the main justification of polygyny, which was accepted by both men and women for centuries of Chinese history.

To give some examples of how polygyny the institution structured and achieved its goals, there was, for instance, the ancient and hallowed principle that there would be only one main wife; all other women were concubines in a distinctly lower position. By law, a concubine should not replace a main wife. As the ancient history called the Zuo Tradition (Zuozhuan) wrote, the two fundamental causes of disorder in a state were the replacement of a main wife by a concubine and the replacement of the main wife's son as heir apparent by the son of a concubine. ${ }^{2}$ The rule that there would be only one wife, who could not be replaced by a concubine, guaranteed the status of the wife, thereby addressing her fear of rivalry with concubines. A similar tool of the polygynous order was the assignment of ranks to the women, providing them with fixed places in the bureaucratic hierarchy of women. Each woman had a title, living quarters, and an established form of income. Each woman enjoyed a sense of security at the same time that it was possible for her to advance in rank, especially, for example, if she bore a son or became the man's favorite. The strict distinction between main wife and concubine had a more general purpose, to define all concubines as lowly and lacking in privilege. Transgressions could result in demotion or dismissal. As the commentator Zheng Xuan (127-200 A.D.)

2. The point is made twice in the Zuozhuan, for which see Zuozhuan (1999): 214, 316. 
bluntly put it, "Concubines all knew that they were lowly and base." ${ }^{3}$ Finally, definitions of virtue and accounts of ideal behavior helped create the illusion of order and stability. An empress was virtuous, for example, when she herself chose consorts and introduced them to the ruler so that he could beget sons. As her biography wrote, Empress Ma, the wife of Han Emperor Ming (reigned 28-75), "often worried that the emperor failed to seek offspring from a wide enough range of women. She would thus recommend and present women from among her attendants." ${ }^{4}$ In cases of jealous rivalry among the secondary wives, the virtuous main wife or empress "knew how to create harmony among the rancorous women of the harem." 5 These basic precepts and strategies appeared in classical texts such as the Rites of Zhou, the Classic of Poetry, and in the chapters on empresses and consorts (Houfei zhuan) of every dynastic history from Sima Qian's Records of the Historian (Shiji) in the first century A.D. to the Qing dynasty (1644-1911) in the early twentieth.

Another key feature of the structure of perversion besides the notion of women gladly serving the polygynist was the notion that the man should not be lustful. Taking multiple wives was not supposed to be because of lust, that is, base and selfish desire, but because the man was a good father and continuator of his line of descent. The polygynist, in other words, was fulfilling his role as good father. In the perverse inflection of polygynous order, this father not only controlled himself, but women helped him control himself by seeing to it that they selected the right kind of women and thus helped prevent him from becoming dissolute. They helped him be a good father who had the most chances to produce sons. The situation is illustrated in a phenomenon that I have elsewhere called "passive polygyny." ${ }^{6}$ In this recurrent scene in Ming and Qing fiction by male authors, the main wife recruits other women as co-wives, concubines, or maids, and makes the decision to do so for the man, who at first may plead his devotion to the wife and avow his lack of desire for other women. In one case, the main wife makes the formal request to her parents-in-law to add her cousin's maid as concubine. In another, the main wife arranges for the husband to take four of the household's most talented maids as concubines. In a third two main wives discuss the methods of keeping their shared husband in check by arranging the living quarters of the concubines so that none will be able to monopolize him. In a fourth the main wife determines that the husband gives

3. 眾妾自知卑賤, from the Mao Commentary to the Classic of Poetry, Mao shi zhengyi (1999): 94.

4. 后常以皇嗣未廣, 每懷憂歎, 薦達左右, see Fan Ye (1995): 10a.409.

5. 能為君子和好眾妾之怨者, from Mao shi zhengyi (1999): 22-23.

6. McMahon (2007): 117-135, which appears in revised form as a chapter in McMahon (2009). 
her his innate, original heart, which is actually their two hearts bound together, then divide the rest of his heart into ten parts for his five other wives. ${ }^{7}$ In short, the man enjoys the privilege of sex with multiple women, but does so only by becoming the passive instrument of female will. Becoming the passive instrument of the other's will is central to the psychoanalytic definition of perversion that I will discuss shortly.

An important feature of passive polygamy is that the women coax and coddle the man, who acts childishly, sometimes cheekily and brazenly, but never cruelly and oppressively. It is as if he yields his privilege of paternal rule and hands it to his wives, who divide the man between themselves and thereby indulge and control him at the same time. The socially privileged man turns into a servant of the women. Thus the 1878 novel, Tale of Filial Heroes (Ernü yingxiong zhuan), in which the man remains boyish all his life while the two strong co-wives manage the household and never get jealous. Novels like the 1878 Courtesan Chambers (Qinglou meng) or the 1906-1910 Nine-times Cuckold (Jiuwei gui) feature a non-naïve, more brazen, version of the same man. These two novels take place in brothels in which the man's subservience to women is merely a semblance of passivity that represents a supposedly sophisticated sense of mastery over women. The man extravagantly subjects himself to women's coddling, prodding, and scolding. He is like a knowing child in the body of an adult man who is a refined expert of the brothel. He moves around with a clever, knowing eye that permits him to enjoy the women's collectively indulgent regard, as if all agree that he is the most adorable man they could meet. ${ }^{8}$

Faintly perverse and brazenly perverse are the two main types of perversion that appear in these examples. There is in general a sense of collusion between man and women that confuses the balance of male and female agency. Is the male Master really in charge? Is he a polygynist of his own will? Or has something unexpected occurred and have women in effect taken over from the inside? That is, is the man subjecting himself to the woman's coaxing and coddling a case of correction from the inside, whereby women set the norms that the foolish man agrees to follow? Does the perverse scenario reach

7. All examples are from sequels to Dream of the Red Chamber. See, respectively, Hou Honglou meng 後紅樓夢, in which Daiyu is the main wife, Baochai the cousin, and Ying'er the maid; Honglou meng bu 紅樓夢補, in which Daiyu arranges for Baoyu to take Qingwen, Zijuan, Ying'er, and Xiren as concubines; Xu Honglou meng 續紅樓 夢, in which Daiyu and Baochai are the wives; and Honglou huanmeng 紅樓幻夢, in which Daiyu is the main wife. Also see chapter 2 of Polygamy and Sublime Passion. Qilou chongmeng 綺樓重夢 also contains this feature.

8. See chapters 5, 7, and 8 of McMahon (2009). 
a point at which women and/or men begin to engage in counter-perverse ways? Let me return to this suggestion after discussing the psychoanalytic definition of perversion.

\section{Defining perversion}

\section{The failure to submit to paternal authority}

So far I have discussed perversion with minimal reference to its definition in the psychoanalytic context. I confine myself to the Lacanian offshoot of the Freudian tradition, which describes perversion as a deviation from the norm whereby the subject reaches a goal other than by socially normative means. That is, the subject achieves pleasure other than by supposedly normal channels. Another way of putting this is that pleasure depends on external and extrinsic conditions outside of the conditions of normative sexuality - e.g., fetishism, voyeurism, or sado-masochism. ${ }^{9}$ Another important notion is disavowal and the splitting of consciousness, as exemplified in the fetish, which the pervert takes as the true object while simultaneously recognizing it as a substitute. ${ }^{10}$ In the

9. See Evans (1996): 138-140, which emphasizes Lacan's distinction between acts and structures of perversion, and concentrates on structures. A pervert does not necessarily engage in acts of perversion, and non-perverse subjects can engage in perverse sexual acts. Similarly, perversion in the institution of polygyny does not mean that all polygynists are perverts.

10. It is "both the object and its absence," in other words. See de Lauretis (1994): 229, italicized in the original. De Lauretis's work is important in defining perversion in a lesbian context, thus reversing the general Freudian exclusion of fetishism in women (34). In her definition of perversion, she gives it a primarily positive connotation by way of destabilizing heterosexual centrality. Based on the theory of Jean Laplanche, she defines sexuality per se as a case of deviation, displacement, and deflection of instinct (12). The basic revolutionary move of Freud is to de-couple the sexual drive from its object, in other words, to say that the sexual drive is inherently "independent of its object" (17, citing Freud). The relevance of these ideas to the theory of homosexuality lies in the notion that perversion is then the norm, not heterosexuality. That is, heterosexual norms are a case of historical contingency; the theory of perversion and by implication homosexuality constitute the theory of sexuality. As she says, "It now seems to me that what I have called Freud's negative theory of the perversions, that which neither he nor his followers could propose or count as a theory of sexuality, that is Freud's theory of sexuality" (23). Her project is to find "in the perversions - rather than in normative, reproductive, teleological, 'normal' sex - a model of sexuality as it is subjectively lived through fantasy and desire" (27). For lesbianism in particular, the lost object is not the maternal phallus; it is not a wish for a penis. Instead what is lost or denied is the female body, which will never be found, but for which the fetish positively substitutes. 
case of the fetish, it is the symbolic substitute for something lacking elsewhere, a lack or deprivation that the pervert sees but disavows - and the pervert excels at obfuscation and disavowal. For example, in psychoanalytic terms, he disavows the permanence of separation from the mother or castration as constituted by the prohibitions of the laws of the Father. In classical Freudian terms, the pervert disavows the mother's castration, refuses to submit to paternal authority, and in doing so finds substitutes for the mother's lack in other objects or parts of the body or clothing. In general, Freud's originality - his revolutionary move was to take "the existence of perversion as a weapon with which to throw the traditional definition of sexuality into question." ${ }^{11}$ His idea, in other words, was that far from being rare, perversion was central to all sexuality. This is especially clear in his observation that no object is the object; fulfillment is always a case of finding substitutes for an original lost object. ${ }^{12}$

It is the Lacanian extension of the basic Freudian definition that interests me, which I summarize via the explanations of psychoanalytic practice and thought. ${ }^{13}$ Some of these definitions are too narrow or clinical for the Chinese context, but need to be spelled out anyway in order to arrive at more adequate general notions. The fundamental clinical situation centers on the male for whom the split between paternal enforcement and maternal indulgence results in surrender to the mother or mother figure. The perverse subject fails to undergo the submission to paternal law, a condition that points in general to the inadequacy of the father function. The father is confused, weak, or absent, for example; the mother is strong-willed and dissatisfied with the father. She coddles the son and prevents him from submitting to fatherly authority. Whatever the case may be, the subject refuses to surrender the pleasure that he obtains from the mother or mother substitute. The pervert has a strong will, in short, which the father or father figure can't break and which the mother indulges. There is an excess of motherly "coaxing" which "engulfs" the man and prevents him from turning into a subject for whom desire is always based on lack. That is, desire is for something that is always a priori unattainable; there is nothing but a series of objects, including people and situations that satisfy desire only temporarily and partially. The pervert, however, refuses to acknowledge the fundamental

11. Laplanche and Pontalis (1973): 306-309, the same idea in the last footnote.

12. The sexual drive is inherently "independent of its object," see de Lauretis (1994): 17, citing Freud's Three Essays.

13. Fink (1993): 38-67. See also the introduction by Rothenberg and Foster: 1-14. Fink says of contemporary psychoanalysis that perversion is usually "an exclusively male diagnosis" (46). For the fact that this is not necessarily so, see de Lauretis (1994), which is a major argument against the orthodoxy of male-only fetishism. My study, however, is mainly focused on the structure of the dominant male perspective. 
lack inherent in desire and its objects. Instead he believes he can skirt this basic truth and obtain the goal by which the other person, the woman in this case, brings the paternal law into being. He thus engages in an inversion of demand. She, not the father, becomes the lawgiver. In other words, the pervert becomes the agent of the woman's desire. He manages to have the woman supply the law that he himself dictates, thus the term inversion of demand. She thereby confirms the pervert in his illusion that there is no split between him and the law. The psychoanalyst would say that the pervert's satisfaction with this state of affairs is superficial, however, because of the anxiety he experiences in that he can only achieve pleasure through the constant toil of compelling others to affirm him. He desires justification and support, but he must have others freely give him that justification and support. I will return to this point below, but in general in the Chinese context we see a similar situation in which the polygynist seeks justification and support, in particular from virtuous women, and thus exemplifies a similar form of constant "work" and "anxiety." 14

\section{The externally imposed rule}

Besides disavowal and splitting of consciousness, the most important notion from the discussion so far is that of the pervert's relation to law. As Gilles Deleuze would say, if he is a sadist, the pervert views himself as higher than the law. He is the ultimate embodiment of the superego. If a masochist, the pervert expels the father and replaces him with the mother, whom the sadist abolished but whom the masochist invests with the superego herself. ${ }^{15}$ To further clarify the pervert's relation to law, we can use the word Law with a capital "L" to refer to the social construct of authority, that is, the rule of the symbolic order, which exerts authority through the effect of discursive construct, institution, or actual human enforcers. The pervert sees the Law as achieving its aura of authority by not only defining transgression but also encouraging and furthering it. That is, in the pervert's eye, the Law succeeds in maintaining its aura of authority through the underhanded gesture of inciting transgression in order to rule against it and thereby make a show of power. In the classic example of perverse behavior already mentioned, the pervert helps his victim to become and remain a victim. He deliberately creates situations in which he is the hero and savior, even deliberately harming the victim so that he can rescue her and thus prove his love for her. ${ }^{16}$

14. See Fink (1993): 45, 47.

15. Deleuze (1997): 60, 90, and elsewhere.

16. As Žižek writes: "a perverse person is the one who intentionally mutilates the woman, distorts her beautiful face, so that he can then continue to love her, thereby proving the 
As said above, self-instrumentalization in the hands of the externally imposed rule is a central notion in the pervert's behavior, where self-instrumentalization refers to behavior in which he gives the appearance of acting not on his own or out of selfish motivation, but as if he were the instrument of some external force or principle. The pervert wants to become integrated into the functioning of the Law. He creates the appearance of enforcing the Law as if he were the instrument of its will, which is utterly impersonal and external to him. In other words, his actions are not the result of personal quirk or selfish desire, but of a greater truth that is beyond him, such as Historical Necessity or the fundamentalist interpretation of a holy text. ${ }^{17}$ In a recent case of an American Southern Baptist minister who raped a young woman, he did so under the guise of counseling her, and while raping her he intoned passages from the Bible, all along insisting that she was guilty. It is as if he was carrying out the will of the Bible and channeling his actions from it instead of exercising lewd desire on an innocent, unwilling victim. In general, the pervert denies the gap that normal subjects experience in the relationship between the human representative of authority and the abstract and/or transcendental condition of authority in the form of the Law or of God. The gap is the same as the fetishistic split referred to above. But the pervert wants to collapse the split between fleshly body and transcendental Law. The normal, neurotic subject is wary of authority, which might be wrong or might be an imposter. But he still believes in fairness. The pervert believes in authority absolutely and longs to function as

sublime nature of his love.” See Žižek (1993): 194, and also Žižek (2000): 59. Another expression of this point can be found in Žižek (2003). As he captures it, the perverse core of Christianity has to do with the grand question that, if in the Garden of Eden "it is prohibited to eat from the Tree of Knowledge in Paradise, why did God put it there in the first place? Is it not that this was a part of His perverse strategy first to seduce Adam and Eve into the Fall, in order then to save them?" (15). In other words, in the pervert's eyes, God created the sin of Adam and Eve so that He could save humanity through the sacrifice of his only begotten son (53). He purposely led humanity into sin so that he could make humanity beholden to him as their savior.

17. One of Žižek's recurrent examples of such an externally imposed Law is the rule of the Communist Party in Stalinist socialism. The leaders of the Party do not exert authority personally or because they possess inherent characteristics such as royal bloodlines. They do so as agents of the Party, which is in turn the agent of Historical Necessity, which dictates the path that society is bound to follow. They are thus the interpreters and executors of the Law embodied in the objectively necessary mission of the Party (which can be substituted in other cases, for example, with the religious institution that carries out the literal interpretation of a holy text). See, for example, Žižek (1997a): 108-09. 
its instrument. Fairness, empathy, and reciprocity do not enter the picture because in his view there are no such things to begin with. ${ }^{18}$

Self-instrumentalization also relates to the pervert's particular form of enjoyment in the sense of jouissance. In parallel with his longing to merge with the functioning of Law, the pervert longs to be merged with the function and direction of enjoyment, a gesture that takes the form of making it look as though he acts not for his own pleasure but as an instrument of the other person's pleasure. In terms of the sexual relationship, sex becomes "an externally imposed task." The pervert doesn't have sex to enjoy it himself, but makes himself a tool of the woman's enjoyment. She assumes the role of the enforcer of Law and pleasure. He works at sex while she supposedly enjoys it. ${ }^{19}$ If we consider the ancient art of the bedchamber in China, the fangzhong shu, we see a similar form of the man's self-instrumentalization. In general, the bedchamber texts teach the man to recognize the signs of the woman's pleasure so that he can lead her to the greatest ecstasy. He must learn to control his ejaculation until she reaches her climax first, after which he should "withdraw while still alive" (shenghuan), that is, without ejaculating. He suppresses his own pleasure, in other words, in order to insure the woman's pleasure and also in order to avoid sexual weakening so that he can have sex with other women soon after. The man in the bedchamber texts works at preventing his ejaculation while monitoring the woman's arousal and reactions to his carefully planned caresses and thrusts. The man's pleasure is hardly mentioned, while the woman's is minutely analyzed - the sounds she makes, the numbness she feels, the look on her face, the flow of sexual fluids. The man, moreover, is the subject of serious warnings about his inherent sexual weakness before he even begins. That weakness can only be overcome by following the instructions of the texts. ${ }^{20}$ Following instructions, using techniques,

18. According to Fink, a crucial distinction between neurotic and perverse subjects lies in the pervert's peculiar relation to enjoyment or jouissance. If the neurotic believes in an authority that is fair and neutral, the pervert can never believe in such purity. Authority and moral principle in general are never free of some form of indulgence in pleasure. There is always some form of enjoyment that takes place in enforcement, even if only in the tone of voice (Fink (1993): 56-57). The pervert therefore sees pleasure everywhere, even in the puritanical strictures of orthodoxy. There is no enforcement of rules without ulterior and pathological motive, where pathological means selfish, prurient, covetous, villainous, and so on, words referring to the general failure of authority to be neutral and fair.

19. See Žižek (1997b): 35, 115-116, and 181, and Žižek (1991): 108.

20. The warnings take the form of statements like, "the woman's superiority over the man is like water's ability to put out fire” (夫女之勝男, 猶水之滅火), or that having sex with a woman is like “riding a galloping horse with a rotten rein" (御女當如朽索御奔馬) or 
and delaying pleasure are all forms of work under which the man becomes the servant of the woman, who in these texts is assumed to be innately capable.

\section{The Freudian bound foot}

Joan Copjec's discussion of perversion directs our attention to a key feature of the Sadean situation, that of compelling the victim to freely choose her submission to pain. Copjec also alludes to Freud's brief reference to footbinding in his proposal that the man revering the fetish of the bound foot is as if thanking the woman for submitting to castration. ${ }^{21}$ As said above, the pervert acts as if the Law is an entity that underhandedly manipulates the rules of the symbolic order. He believes that he can integrate himself with the functioning of the Law and that he can embody the Law in himself. In terms of his relationship with the woman, it is as if he can bring the woman into existence by compelling her to submit to his pre-ordained definition of her as Woman, with a capital "W." Although there is no capital-letter Woman to begin with, the pervert believes there is and he creates roles for her - roles of so-called "pre-ordained subjection" (Copjec) - that he expects her to perform. But, as already indicated above, the pervert does not like the appearance of merely forcing people to subject themselves to him. He has to have them freely choose to do so.

By way of explaining the point about free choice further, it is a common belief that the sadist treats the victim as an object to be abused and exploited and that the sadist dominates the victim by turning her into a sheer instrument of pleasure and abuse. But this is not what sadism is necessarily about. The sadist does not seek simply to suppress the victim's freedom or to enjoy the victim's suffering. Instead, the goal is to compel the victim to "submerge" herself in pain. It is not just a matter of inflicting pain but of achieving the goal whereby the victim ceases resisting and trying to rise above the abuse. The victim freely, of her own will, submits herself to the state of subjection. ${ }^{22}$ In general, the pervert manipulates the sexual relation in a way that leaves it up to the other to decide to submit. For him, his enjoyment is a duty, "a service he performs for the Other."

“nearing a precipice over a deep pit of sharp knives and afraid of falling in” (如臨深坑 下有刃恐墮其中). See the Sunü jing 素女經 as found in Sunï jing (1976): 19, 33.

21. Copjec draws from Sartre and Deleuze, among others, and echoes the definitions of Žižek and Lacan. See Copjec (2002): 222-231. The central work of Sartre in this case is Being and Nothingness, Lacan's article, "Kant with Sade," trans. James Swenson, October, no 51 (winter, 1989), and of Deleuze (1997).

22. In summarizing the behavior of the pervert, Copjec (2002: 223) says that he wants to "ensure that gaze and vision, desire and law, conscious and unconscious no longer contradict each other but inhabit the same palne, and attempts to force them to coalessce": 223. 
In saying this, Copjec cites Lacan's theoretical innovation, which was to say that the pervert is "the servant of the Other" (her emphasis). That is, the pervert is both servant and torturer. The Other is grateful for the pervert's abuse, while the pervert serves the Other "precisely by torturing him." 23

Here is where we can turn to the Chinese example by picking up on Copjec's reference to Freud's statement about bound feet, which was remarkably apt even though he knew nothing about the sources I discuss below. The bound foot is an exemplary case of fetishistic perversion. In his brief remark, Freud said that "the Chinese custom of mutilating the female foot and then revering it like a fetish after it has been mutilated" makes it seem "as though the Chinese male wants to thank the woman for having submitted to being castrated." This remark comes at the end of his short article on "Fetishism" as one of several examples of fetishistic disavowal, that is, of "two mutually incompatible assertions." In other words, the man mutilates the woman but thanks her for accepting the mutilation as if it was her freely willed submission to the Law. Thanking her is the result of her freely choosing to accept mutilation. Copjec via Lacan proposes to reverse the logic of Freud's statement by saying that it is instead the woman who thanks the pervert for torturing her. But the result is the same: whoever thanks whom, it is the woman who freely agrees to mutilate her feet. The mutilation happens not because of the pervert's personal wish, but because the woman wills it. Again, it is important to note the split of consciousness in the case of the pervert, that is, the fact that he is both servant and torturer. Being both servant and torturer is as if swearing love to someone by vowing to care for her in all situations, but then secretly causing her to suffer, and finally stepping in to care for her in her distress. In this case, the man has the woman mutilate her feet, which cripples her, so that he can then, as it were, do the walking for her. ${ }^{24}$

Freud's statement, however, appears remote from the perspective of a historian of China, especially the idea that the man mutilates the foot and then reveres it or that he thanks her for binding her feet. The idea that the man has the woman mutilate her feet is to begin with problematic since we do not even know how or when footbinding began. Who decided to do it? What was the rationale? We must now turn to the historical scene in China by way of correcting Freud, so to speak, and nevertheless still insisting that he was basically correct.

23. Her emphasis, Copjec (2002): 225, 227-228.

24. Freud is cited in Copjec (2002): 228, from Freud (1953-1974): 157. 


\section{Footbinding in China}

If Freud had further delved into China and bound feet, he might have added a few details that we can now obtain from more recent studies. ${ }^{25}$ From what we know of the daily existence of bound-footed women, the notion of the man mutilating the foot, then revering it, tests our credulity. As just said, we do not even know when or why footbinding began in China. There was never anything like a central directive that decreed that women should bind their feet. It is as if the father was absent, but an ingenious response to his authority emerged anyway. To understand the practice, we can only trace back from its material manifestations and the words said about it over the centuries. It is from these records, I would propose, that we see perversion at work, even though we do not necessarily see a pervert in every individual father or husband of every bound-footed woman.

Let us briefly summarize the main historical features of bound feet, beginning with the earliest material evidence, which comes from the tomb of a woman who lived from 1227 to 1243 . The indication is that the custom - or some version of it - was already common among women in the families of high officials by the early thirteenth century. We have no archaeological record of the first bound feet, nor any data of its average numbers and spread. Nevertheless, as Dorothy Ko writes, footbinding became "the single most important experience in a woman's life between the thirteenth and nineteenth centuries." Its development was a long process beginning in the eleventh century after the fall of the Tang, most probably among entertainers, then spreading to respectable families in which women

25. For the history of footbinding, I will paraphrase the findings of Dorothy Ko in Every Step a Lotus: Shoes for Bound Feet (Berkeley: University of California Press, 2001), especially p. 21-24, and Cinderella's Sisters: A Revisionist History of Footbinding (Berkeley: University of California Press, 2005). I have written a book review of Cinderella's Sisters, from which I also draw and which appears in Nannü: Men, Women, and Gender in Early and Imperial China, $\mathrm{n}^{\circ} 9$ (2) (2007): p. 395-400. The other main source on bound feet has for many years been Howard Levy's Chinese Footbinding: The History of a Curious Erotic Custom (Taibei: Nantian shuju, 1984). Ko notes other sources in Every Step a Lotus, p. 148. The best theoretical treatment of footbinding is Angela Zito's “Bound To Be Represented: Theorizing/Fetishizing Footbinding," in Fran Martin and Larissa Heinrich, eds, Embodied Modernities: Corporeality, Representation, and Chinese Cultures (Honolulu: University of Hawaii Press, 2006: 21-40. One of Zito's main points is the failure of cultural feminists and others (beginning with nineteenthcentury missionaries) to properly historicize footbinding, in particular their tendency to "reduce and dismiss living context" (p. 22; see also p. 33-35). Freud would fall into the same category. Zito focuses on footbinding as "embodied subjectification" (p. 23) and usefully distinguishes between footbinding in terms of its "social production" (Ko's and my concern) and the "manner in which we have received news of it, and how it continues to engage us as empowered theorizing subjects" (p. 24). A fine summary of the definition and uses of the concept of fetishization is on p. 25. 
decided to copy the entertainers. The custom was never universal, but was more popular in the north. The way feet were bound changed over time and was never uniform at any one time. By the time it became fully established, it was mainly centered among upper-class women, remaining so until the seventeenth and eighteenth centuries, when peasant women also began to bind their feet. Peasant women, in turn, were the last to stop binding their feet in the late nineteenth and early twentieth centuries; some elderly women still live today whose mothers began binding their daughters's feet even after the rural and urban elites had abandoned the custom forever. The practice was already preceded by many centuries of attention to the smallness of women's feet, as found in literary references to beautiful women from as early as the third century. There was a recurrent focus on the sensuality of the woman's tread. By the fifth century the relation between "lotus, dancing, and sensuality" was fixed, "golden lotus" eventually becoming one of the main terms for bound feet. Some form of binding or wrapping of the feet was common in both poetry and storytelling by the tenth century, although this was not necessarily a sign, as many have taken it, that footbinding as it was eventually known already existed by that time. The earliest convincing textual references originate in the eleventh century, while the most popular legendary origin comes from a fourteenth-century description of a tenth-century dancer, that is, Yaoniang, a consort of Southern Tang Emperor Li Yu. ${ }^{26}$

When it comes to interpreting the meaning of footbinding, for a long time the focus has been on the pain and injustice of footbinding, on the one hand, and the exotic and erotic aspects of small feet, on the other. Dorothy Ko's revision is to insist that footbinding was a customary feature of mundane reality. It took place in all kinds of households, including ones that in binding their daughter's feet were enforcing the highest values, as she says, of "domesticity, motherhood, and handwork." ${ }^{27}$ A historian like Ko concentrates in particular on the aspects of domesticity and womanhood, which valued women's diligence in the upbringing of children and all manner of women's work, of which the binding of feet and the design and creation of shoes for the bound foot were highly respected activities. Ko's central point, especially in contrast to Freud's statement, is that it was women who managed the binding of their daughters' feet. A man's erotic

26. See Ko (2001): 12, 34, and 35. On the demise of footbinding, see chapter 3 of Bossen (2002). For Yaoniang, see Wu (1983): 18.269, referring to fourteenth-century sources.

27. Ko urges avoidance of merely viewing "footbinding as a senseless or perverted act" (Ko (2001): 15). An example of captivation by the exotic and erotic is the image many have had that the Chinese man "would put the entire foot into his mouth, and the woman would stimulate the man by touching his penis with her feet." This is quoted from Steel (1996): 94, without citation of source. Although I do not deny the possibility of practices like this, I have not found instances in the erotic fiction that I have read in the Ming and Qing. 
attraction to the bound foot was not the centrally stated reason for the practice. Instead the main stated reason for footbinding was to improve a daughter's marriage prospects, which depended on her having well-bound feet. As something women were in charge of, bound feet were a sign of women's control over their own bodies - though I will question this notion in the next section after returning to the concept of perversion. An example of women's agency in the practice of footbinding was their creativity in the fashioning of shoes for the bound foot. The shoes were notable in variety, style, and artistic input, and underwent change in design throughout the period of production to the very end of the custom. In short, what many used to think, that is, that footbinding was a result of the man's erotic fascination with tiny feet, is just one of many ways of explaining it. There are a few additional features about footbinding that will add more perspective to its interpretation as a form of perversion.

First, men were not universally in favor of footbinding. Many all along expressed distaste and outright condemnation. At the same time, literati were fascinated with the custom. The sixteenth century in particular saw a surge in literati interest as scholars traced the origins of the custom (the discussion of footbinding prior to the nineteenth century was centered on origins) and detailed desirable features of feet and shoes, including precise measurements. Although a common modern perception has been that the intention behind footbinding was to immobilize women and thereby enforce sexual segregation, the philological discussions these men engaged in generally drew no link between footbinding and the guarding of female chastity. Women were in fact still quite mobile, although social custom in general had already dictated for centuries many forms of sexual segregation.

Next, as just noted, the method of footbinding changed over time. The sixteenth century saw the method undergo a major change in which the four toes, not including the big toe, were folded under. Footwear and excavations from the Song (960-1279) and Yuan (1271-1368) periods indicate that the goal in earlier times was to make the foot narrower and the toes pointed, but that the arch was not broken as it would be in the later phase. The cleavage formed by the broken arch became the site of erotic fascination, hence the beginning of the so-called "cult of the golden lotus." Along with the "three-inch golden lotus" came the advent of high heels, the fashion that readers have long noted in the sixteenth-century novel Golden Lotus (or Plum in the Golden Vase, Jin Ping $\mathrm{Mei}$ ). Although the old way of leaving the sole flat never completely disappeared, the new way became fashionable first among the elite, then downward along the social ladder.

Third, abolishing footbinding did not meet with direct and transparent acceptance. It was a deeply accepted tradition. For many the custom was a sign of the 
superiority and inviolability of Han-Chinese women. In the early Qing dynasty, the Manchu rulers tried to abolish footbinding, which was alien to them, and never permitted Manchu women to adopt the custom. At penalty of death, Han men acquiesced to the Manchu order to grow queues, but Han women refused to relinquish their bound feet, which thereby took on meaning as a treasured symbol of Han female identity. The movement to abolish footbinding in the twentieth century finally met with success, but not without initial hesitance and even refusal. It even became linked among some with Han Chinese nationalism. The Beijing University English professor Gu Hongming (1857-1928) is an extreme but fascinating example. Born in Penang of a Chinese father and perhaps an European mother (of whom he never spoke), he was educated in Europe and landed in China in his early twenties. He suddenly felt that he had a home and a nation, saying that he was finally able to be a Chinaman. He wore a queue even after the fall of the Qing, when the queue was abolished, and thought that bound feet were a sign of supreme womanhood and a site of inviolable sanctity in an age of trauma and transition. To him European woman were grossly masculine, while the Chinese were models of passive serenity. He had a bound-footed Chinese wife and a Japanese concubine (who presumably would not have had bound feet since it was never the practice in Japan). He supposedly thought of the Chinese wife as his stimulant, the Japanese one as his sedative. Although he was not open about these tastes during his lifetime, accounts published in Taiwan in the 1970s reveal that he extolled the properties of the bound foot. He was a nationalist and patriot who in his opposition to foreign imperialism took the Chinese woman as an icon of Chinese purity and sovereignty. ${ }^{28}$

Gu Hongming gets us back to the territory of perversion, especially in his super-valuation of the woman by way of supporting the cause of Chinese nationalism. Two more examples are useful for clinching how perversion applies to the practice of footbinding. The first example is from early Republican accounts of footbinding that cast the practice in a nostalgic light and extolled its pleasures, as excellently discussed in Dorothy Ko's recent work. A recurrent feature is the story of a man's or boy's encounter with a bound-footed woman, which is told as a distant memory, through a haze of intoxication, or as a posthumous account. Some form of distancing is common, especially in the form of the device of the "all-seeing eye of the boy." One story is about an encounter between a twenty-something maid and her young male master who is half as old. The maid and the boy have an affair in which they play games, in one of which the boy retrieves a tiny bag of water chestnuts from the crevice of the maid's foot. The fondling of her foot arouses her and

28. See Ko (2005): 32-35, and Liu (2004): 168-180. 
makes him ejaculate. The maid and the boy never have intercourse, but play erotically together every day. The story insists that playing with the foot is categorically different from actual intercourse. In Ko's words, the "innocence of prepubescence allows the voyeur to gain entrance into the female quarters, play all he wants with an adult woman with bound feet, and narrate the sensuous excitement of kissing the foot or sniffing the toe without social or moral sanction." 29

The all-seeing eye of the boy is key to the function of perversion. The boy is not really a boy, but an all-seeing grown man perversely taking on the role of a passive participant receiving the benefit of the woman's sexual attentions. The all-seeing eye takes on further significance when juxtaposed with the second example, taken from a passage of three hundred years earlier. The seventeenth-century author, Li Yu ( ca 1610-1680), advised men about judging a woman's bodily appearance, including hands, bound feet, gait, and inner self as revealed by her external features and behavior. Have her walk back and forth, he said, and observe her sense of balance, which will say everything about her feet. The key, Li Yu says, is to observe her from a level lower than her eyes, that is, to reverse the normal hierarchy and for the man to "stay passive" and "lie low." In this way the man compels her to look back at him instead of shyly averting her gaze, as she would tend to do if he were standing and looking at her. He will thus "catch her natural eye movements" and find the woman who is finest in poise and balance. ${ }^{30} \mathrm{Li} \mathrm{Yu}$ 's approach recalls the device of the all-seeing eye of the boy. In both cases the man reverses the categorical distance between man and woman by occupying a lower position than the woman, whether as a boy versus an older woman or as a man lying low and looking up at the potential concubine. The object is to blur and erase the distance between the two and thereby manipulate or engineer the vision of the woman. To manipulate the woman's vision is also to create a pre-ordained role for her. Reversing hierarchy and erasing distance are crucial features of perversion. It is a case of disavowal and split consciousness, which is apparent in the man, $\mathrm{Li} \mathrm{Yu}$, who is as if to say that he "knows" he is the buyer and that she is one of many potentially being bought, but that "anyway" he can still capture her in her natural form, as if he were invisible. Like the boy, he pretends passivity, has the women become active, while all along he retains his role as the dominant party.

29. Ko (2005): 85-86.

30. Ko (2005): 155. 


\section{Polygyny, footbinding, and the structure of perversion}

What is in general remarkable about footbinding, to put it naively, is that it is something that seems impossible for women to want that nevertheless becomes something that they willingly take on and manage. What could be going on? There is no single, ultimate explanation, even one that claims to describe the "deep structure" of footbinding and its unconscious psychic meaning. Still, the next logical step is to say that if footbinding could be mundane, then so could something like perversion and fetishization. In her study, Dorothy Ko marginalizes Freud's equation of the fetish of footbinding with "a man's projection of his castration anxieties onto the body of the woman." Taking footbinding as a sign of women's castration is an example of a blanket statement that in turn marginalizes women's participation in footbinding. Still, one approach does not abolish the other. Taking footbinding as a sign of women's castration is an example of a narrow approach only if we refuse to submit it to the historical test, which means placing it in the social and material context that we have just outlined. After doing so, we can then apply the elaborations upon perversion provided by psychoanalytic theory and practice. With the evidence I have gathered so far I would add to one of Ko's thesis statements about footbinding, namely, that "men's experience of footbinding was by definition an encounter with a body not their own." 31 I would modify this to: Men's experience of footbinding was by definition an encounter with a body not their own, which they felt compelled to act as if it were their own. Another way of saying this is: Men's experience of footbinding was by definition an encounter with a body not their own which they dreamed would act as if it were their own. The encounter with such a chasm results in the perverse attempt to erase or disavow the chasm. To say that footbinding is about men's encounter with a body not their own is not enough. Men do not stop there, in other words, but create situations that make up for the gap. Two more examples from Qing fiction help illustrate the program of perversion.

\section{A gender-fluid polygyny}

It is in literary portrayals of ideal polygamy that perversion reaches its fullest potential, as in Return to Dream of the Red Chamber (Honglou fumeng), for example, the longest sequel to Dream of the Red Chamber, written in the late 1790s. It illustrates one of the central features of almost all sequels to Dream of the Red Chamber, the creation of a Baoyu who is a successful polygynist who marries not only Daiyu and Baochai (or their reincarnated equivalents),

31. Ko (2005): 2, 151. 
but also other cousins, unrelated women, and maids (in the original novel, he loved Daiyu but was tricked into marrying Baochai, after which he left the family to become a monk). In this sequel Baoyu is reborn as Mengyu and has twelve wives. He is fair to everyone and follows one of the oldest cardinal rules of Chinese polygyny by harboring no favorites. But he pushes the ideal further by engaging in an extreme and perverse form of gender fluidity, which features the erasure or blurring of gender boundaries and exchanging of gender roles. Gender fluidity was a common feature of Chinese fiction in the Ming and Qing, including Dream of the Red Chamber, which many readers have noticed and commented upon. The erasure of gender boundaries and the exchange of gender roles occur in stories about love affairs in which, for example, the man looks feminine and the woman dresses as a man. In Dream of the Red Chamber Baoyu is a feminine boy, while Daiyu's room looks like a boy's. As in other Ming and Qing love stories, they share a common character in their names, in this case jade $(y u)$. In some of their social gatherings, they and other young men and women overlook normative rules of gender and social hierarchy, such as appellations and seating arrangements. The result is the creation of a temporary world in which the low becomes high and in particular the woman acts on a par with the man or the servant with the master. There is a brief sense of universality that lifts the strictures of ordered social roles and renders irrelevant the Master's discourse. The result is an atmosphere of liberation and freedom from constraint.

In the sequel Return to Dream of the Red Chamber, however, gender fluidity becomes a tool by which the polygynist yields but still underhandedly retains his central position. Baoyu's reborn self, Mengyu, is all "sentiment" and no "lust," it is said. In a key passage, he consorts with his wives and maids in such a way that he is "not even aware that he is male and they are female. As far as he is concerned, someone else's body is mine, and mine is someone else's... Even if one of the women is sponging herself or taking a bath, he comes and goes as he pleases and no one minds." 32 That the women do not mind Mengyu's coming and going as they wash and bathe is as if to say that they accept polygyny and deliver it to the man without his asking. In this carefully established atmosphere of chaste intimacy, he hugs one woman, helps another put on her shoe (19.213), becomes mesmerized as he watches the group of them (20.223), and licks the rouge off someone's lips (28.309-310). Return to Dream of the Red Chamber

32. 並不知自身是男, 他人是女. 覺得他的身子就是我的身子, 我的身子就是他的身 子... 那怕遇着擦身洗澡呢, 大爺來就來, 要去就去, 聽其自然; see Chen Shaohai (1988): 26.287. Chapter 13 contains the first major explication of his nature, including the fact that the women "forget that he is a man" (Chen Shaohai (1988): 13.139-140). See also chap. 2 . 
is a novel that has promised not to engage in pornographic detail. The sexual acts of the polygynous family so prominent in other works lie just to the side or behind the scenes. A woman who accidentally finds a dildo hidden in another woman's bed clothing, for example, gets aroused contemplating it. The wetness between her legs is an example of a perverse detail, a fetishized description of actual sex with a dildo, which is nowhere else described (29.314).

Inspired by the original novel's notion of yiyin, "lust of the mind," the author of Return to Dream of the Red Chamber pushes gender fluidity to the extreme of gender-oneness and transparency, erasing the difference between male and female and thus removing the tensions inherent in polygynous families. The portrayal is perverse in that the author makes the marriage appear natural and unproblematic. Jealousy is gone because the man is supposedly no longer a man; and therefore the multiple wives supposedly have no more reason to be jealous. ${ }^{33}$ But he still manages to have sex with his wives, as a polygynist would. The scene presents a genteel version of perversion, in short. If one is used to perversion being crafty, knavish, or brazen, this is another type, but a type nevertheless.

\section{Looking at his wives mourning his death}

Another example from late Qing fiction illustrates the same focus on disavowal of boundaries, in this case from the perspective of the Master polygamist's all-knowing eye, which appeared above in the case of early twentieth-century nostalgia about footbinding. The 1878 novel Courtesan Chambers (Qinglou meng) contains a scene about the soul of a dead man observing his wife and concubines preparing his corpse for burial. The scene is probably inspired by the one in Dream of the Red Chamber in which Baoyu, after being beaten savagely by his father, imagines his cousins and other girls in the household grieving over him if he were to die (chapter 34). In Courtesan Chambers, the vision fulfills a wish the man once had that he would lie dead before a group of beauties who would grieve over him as they sent him off to the after life. After watching them, he re-enters his corpse and joins his wives for another period of mortal life after which he dies for the second and final time, saying that he has now "enjoyed all there is to enjoy in the rooms of wives and concubines." ${ }^{34}$ $\mathrm{He}$ and his wives then all join as immortals in heaven. Looking at his wives mourning his own death and then suddenly sitting up in his coffin describes

33. From "in this carefully established atmosphere" to "no more reason to be jealous" is from McMahon (2009): 40.

34. The edition used is Yu Da (1990): see 35.240-241 and 58.395, which contains the quoted passage: 妻妾房帷之樂已領略盡了. Words in this paragraph are from McMahon (2009): 88-89. 
the perfect circle of the polygynist fantasy, as does claiming total enjoyment of women and then dying. In effect he claims control over life and death, enjoyment and its reversal, thereby merging with the cosmic law of the cycles of pleasure and pain, living and dying. There is no gap between the hero's perspective and that of cosmic law - the erasure or disavowal of that gap, as we know, being a fundamental feature of perversion.

Looking at his own corpse is another version of the all-knowing, all-seeing eye, which in essence has to do with the male hero being able to look at women without their being able to look back. The all-seeing eye occurs elsewhere in Qing fiction about polygynous and philandering men, as it does in the story above about the boy and his love affair with the bound-footed maid. The fact that it is a boy who enjoys the woman's bound feet and engages in erotic play with her makes it a supposedly innocent act, but in fact the author of the story is an adult man who erases the sense of transgression by envisioning the woman through the eyes of the innocent boy. The boy's eyes are all-seeing eyes because behind them are the adult male author and readers enjoying the view of the sexual woman who accommodates the young boy. The psychoanalytic notion of gaze best describes the function of the all-knowing eye. Gaze refers to the fact that people never look at me from where I expect them to. ${ }^{35}$ No one is seen in the way she wants to be seen or thinks she is seen. The important distinction here is between the look and the gaze, where the gaze comes from the perspective of what is looked at, which never coincides with the subject's look. The split between the subject's look and the object's gaze is a visual form of the split between male and female subjectivity. The knowing eye looks at an object without that object looking back at him. The look back is particularly missing in the novels that portray the most brazen and knavish polygynist-philanderers, where brazen and knavish are alternate words for perverse (such as Courtesan Chambers, Nine-times Cuckold, and Revisiting the Silken Chambers, that is, Qilou chongmeng, as well as individual scenes in other novels). Courtesan Chambers presents one of the most farcical examples of the disavowal of the gaze in nineteenth-century fiction as the hero's disembodied soul looks at his own corpse while his wives weep over him. It is a case of the knowing eye that sees himself without others returning his look, as if he sees all, but they see nothing.

35. For a fuller explanation of the knowing eye in Chinese fiction, see McMahon (2009): chapter 8. Lacan's formula for the gaze is, "You never look at me from the place from which I see you," in Lacan (1981): 103. These ideas are based on the assumption that there is no transcendental position of ultimate neutrality. The gaze, in other words, stands for the absence of the transcendental position. See Copjec (2002): 210-212; and Evans (1996): 72. 
The woman's lack of jealousy is similar to the woman's not looking back at the man. Jealousy is a form of resistance to polygyny, as is the woman's gaze at the philandering man. Disavowal of jealousy is like disavowal of the woman's gaze. Similarly, when the seventeenth-century Li Yu advises the man who is about to purchase a concubine to observe the woman from a lower level, he reverses the normal hierarchy and has the man "stay passive" and "lie low." 36 In thus compelling the woman to look back at him instead of shyly averting her eyes, the man engages in the perverse act of engineering the woman's look. As with the all-seeing eye of the boy, in both cases the man manipulates the categorical distance between self-man and other-woman by pretending to be lower than she, that is, in perverse terms, by becoming her servant in order to take her over.

In general, the perverse polygamist subjects himself to the wives's needs and thereby gains their participation in polygyny. He obscures sexual boundaries and engages in non-sexual intimacy by way of creating the perfect polygyny, which is all about the polygamist gaining access to multiple women in a free and transparent way. The perverse disavowal or split in consciousness is apparent in that the man is as if to say that he "knows" he is one man and they are many women, but that "anyway" he can still obtain their agreement that he can have sex with all of them. Erasing the difference between male and female or reversing their roles creates a semblance of transparent gender-oneness. The goal all along is to remove jealousy and rivalry between women and in general to disavow their resistance to situations that put them at a disadvantage vis-àvis the man and other women. The man seeks to usurp female agency, in other words, but to make it appear that the woman is actually in charge. He endeavors to make the female subject transparent to the male. Transparency allows a single eye, that of the pervert, to behold all subjects at once. It is under that eye that women subject themselves to polygyny and footbinding, even going beyond mere social submission and taking the step of mutilating themselves in order to inscribe physical weakness and deficiency in their very bodies.

\section{Conclusion: Jia Baoyu the counter-pervert}

Perversion names an extreme scenario that nevertheless tinges many if not all scenarios as a sort of ultimate destination to which the polygynist Master potentially arrives. But polygyny does not always arrive there and often stops short somewhere else. Women do not necessarily conform to perverse expectations, while men do not necessarily promote the perverse agenda. The logic and

36. Ko also uses the word gaze in a similar sense, Ko (2005): 155-156. 
structure of perversion is something that floats above or lies below, sometimes reaches extremes, and often is hardly visible. There are also cases of counterperversion, or escape from perversion, within what is nevertheless an institutional or social implication of perversion, examples of which include Jia Baoyu and other characters in Qing fiction, especially as seen in the nineteenth-century novels Precious Mirror of Boy Actresses (Pinhua baojian), Traces of the Flowery Moon (Huayue hen), and Flowers of Shanghai (Haishang hualie zhuan). Women also engage in resistance to or escape from perversion through their multiple ways of manipulating polygyny and managing footbinding.

A good device for considering whether or to what degree a person or a character subscribes to the perverse agenda is to ask whether and how he or she engages in forms of self-instrumentalization. The pervert pretends to embody the Law, to be the incarnation of its functioning, like the Han dynasty usurper Wang Mang, one of Chinese history's greatest perverts, who deliberately planted portents predicting and justifying his rise to power. That is, before usurping the throne, Wang Mang made sure to avoid showing his ambition to rule. Instead, he had underlings present him with a series of petitions asking that he be emperor and reports of portents indicating that he should ascend the throne. He steadfastly acted as if the role of emperor was externally imposed. In other words, he was not an usurper but a ruler with a mandate from above and without. A constant feature of the perverse subject is that he seeks justification and support from respectable people and legitimate sources. Likewise, Wang Mang the father-polygynist did not want to appear to have multiple wives because he was lustful and selfish, but because the order of things dictated that he should have multiple wives. Long before he usurped the throne, he had already created the impression that he had "one wife and no other." He wished to counter the effect of previous Han rulers who over-indulged their wives and concubines. In fact, he had fathered children by women other than his wife, but he called the women "attendants," not concubines. After he became emperor, however, his wife died and he was in need of a new one. A proper emperor must have an empress and consorts. An official recommended that he take an empress and 120 consorts because, as the official cited from the well-known passage in the Rites of Zhou, the ancient Yellow Emperor did so and therefore Wang Mang also should. ${ }^{37}$ Only then did Wang Mang decide to recruit an empress plus precisely 120 concubines.

37. See Ban Gu (1962): 99.4054 and 99.4166, and Sun Yirang (1987): 552. Joan Copjec writes that "[c]linical evidence shows that the pervert is one who constantly seeks out respectable people... not as mere delegates but as actual, infallible instances of the law" (Copjec (2002): 229). 
Escaping and resisting the perverse agenda is apparent in women who resisted and manipulated polygyny to their own benefit. In general, social and economic conditions were in the polygynist's favor since women could hardly exist independently of men. In the Ming and Qing, the market in concubines and prostitutes thrived and was a constant source of supply for men who could afford to buy their services. The sexual ratio was severely skewed, with the number of males far exceeding the number of females, the result of which was to make wealthy men more desirable as mates than luckless, penniless men. Disadvantaged women might welcome becoming a concubine rather than being forced into prostitution. They might prefer becoming a bondservant or maid rather than marrying a penniless man. From bondservant one could rise to favorite concubine. As for the polygynist, he could serve as a kind of savior, preventing women from suffering dire fates. The woman, on the other hand, might be calculating her odds of survival and gladly enter his family, as numerous Ming and Qing stories illustrate. She might bond in a stronger way with one of the other wives than either of the women bonded with the husband, in which case the women's lack of jealousy did not conform to the lack of jealousy designed by the pervert. If the woman was like Pan Jinlian, she would pretend to accommodate the polygynist, but actually take every opportunity to grasp for personal advantage. She would become like a parasite upon the body of the polygynist master, attacking and eroding his power in both brazen and underhanded ways. ${ }^{38}$

Although the perverse polygynist would not admit it, polygyny was always split because of the fact that women's resistance to polygyny and their objection to subordination to men would never disappear. When women's resistance becomes the central theme of a story and when that story resists resolving itself into the happy ending of polygynous harmony, then we have cases of the resistance to perversion or counter-perversion. The activation of a sense of gaze upon the polygynous man likewise amounts to a case of counter-perversion. The pervert disavows the gaze, but the fictional author insists on the gaze when he portrays the polygynist from the perspective of women and others whom the polygynist cannot control or predict. A sort of egalitarianism even emerges in some cases such as Dream of the Red Chamber. The love affair is based on the ideal of the sublime relationship between self-selecting soul mates, Lin Daiyu and Jia Baoyu. Their love is fractured and unattainable, threatened by the manipulation of parents and other relatives, but not by Baoyu's polygynous desires. He does have many women to choose from, and Daiyu repeatedly senses her isolation and rejection. Moreover, Baoyu lives in a family in which his father,

38. See McMahon (2009): 18-19, citing Ding (2002). 
uncles, and cousins take concubines, and in which he is expected to do as well. His elders already give him the maid Xiren as sexual partner even before they decide whom he is to marry. But she is appointed as a kind of moral guardian, while he fails to take advantage of her as convenient sexual companion except for their initial virginal tryst. He forms a stronger but strictly chaste relationship with Lin Daiyu, his equal in social status. Both struggle to express their mutual devotion and fall deeply in love while never being able to announce their feelings and act upon them. Finally his family dictates his marriage to Xue Baochai, Lin Daiyu dies, and he leaves his family to become a monk, thus dramatizing his broken-heartedness over the loss of Daiyu. It is hard to imagine a greater contrast between a figure like Wang Mang or Mengyu, on the one hand, and Jia Baoyu, on the other. At times Baoyu almost acts like the perverse man who behaves in a cheeky childish fashion as he flits from one woman to another, expecting them all to indulge and coddle him. But in general Baoyu stands for a trend apparent throughout the Ming and Qing in which the woman's gaze upon the man is persistently present and in which there is hardly a chance for the perverse and passive polygynist to make his appearance.

As for bound feet, the fact that it was an affair that women managed and controlled can also be read as a case of counter-perversion. Their management of footbinding proves that, however perverse the Law of footbinding may have been, women did not necessarily submit to it in perversion's precisely preordained way. Footbinding could even become a form of political resistance, as we saw in the failed Manchu attempt to abolish the practice at the beginning of the Qing. Another possible way of interpreting footbinding is to pose the radical question: what if the custom was entirely a decision made by women? Although it is not really feasible to ask whether anyone, male or female, made such a specific decision, nevertheless even if we say that women did originate footbinding, they still would have done so within a male-dominated social system that invited such actions. Mutilate yourself, do it in a refined fashion in which you hide your suffering and accept it as an universal given, but manage it all by yourself. The same social system invited women to support polygyny. Let your husband take multiple wives, be proud that he does so, accept it as a fundamental human law, and help him accomplish it. Taking responsibility for footbinding and supporting polygyny were both part of the perverse agenda's attempt to gain its victims' freely willed submission. To be sure, the perverse agenda was not the only agenda. Women could not escape polygyny or overthrow it, but they could exert emotional and moral control that had concrete effects on the marriage. The perversion that lay within these practices could only hope to provide its players with pre-established scripts but could not eradicate the function of the gaze nor perfectly control the nature of submission. 


\section{BibLIOGRAPHY}

BAN Gu 班固 (1962). Hanshu 漢書. Beijing: Zhonghua shuju.

Bossen Laurel (2002). Chinese Women and Rural Development: Sixty Years of Change in Lu Village, Yunnan. Lanham: Rowman and Littlefield.

Chen Shaohai 陳少海 (1988). Honglou fumeng 紅樓復夢. Beijing: Beijing daxue chubanshe.

CopJec Joan (2002). Imagine There's No Woman: Ethics and Sublimation. Cambridge, Mass.: The MIT Press.

Deleuze Gilles (1997). Coldness and Cruelty. In Masochism, Jean McNeIL (trans.). New York: Zone Books.

Ding Naifei (2002). Obscene Things: Sexual Politics in Jin Ping Mei. Durham: Duke University Press.

Evans Dylan (1996). An Introductory Dictionary of Lacanian Psychoanalysis. London/ New York: Routledge.

FAN Ye 范曄 (1995). Hou Hanshu 後漢書. Beijing: Zhonghua shuju.

Fink Bruce (1993). Perversion. In Molly Anne Rothenberg, Dennis A. Foster, and Slavoj žIžEK (eds), Perversion and the Social Relation. Durham: Duke University Press: $38-67$

FREUd Sigmund (1953-1974). Fetishism. In The Standard Edition of the Complete Psychological Works of Sigmund Freud, James STRACHeY (ed. and trans., in collaboration with Anna Freud; assisted by Alix Strachey and Alan Tyson). London: Hogarth Press, vol. XXI.

Gamman Lorraine and MaKinen Merja (1995). Female Fetishism. New York: New York University Press.

Ko Dorothy (2001). Every Step a Lotus: Shoes for Bound Feet. Berkeley: University of California Press.

Ko Dorothy (2005). Cinderella's Sisters: A Revisionist History of Footbinding. Berkeley: University of California Press.

LaCAN Jacques (1975). Encore. Paris: Éditions du Seuil.

LaCAN Jacques (1977). Écrits: A Selection, Alan SHERIDAN (trans.). New York: W.W. Norton.

LaCan Jacques (1981). The Four Fundamental Concepts of Psychoanalysis, Alan SHERIDAN (trans.). New York: W.W. Norton.

Laplanche Jean and Pontalis Jean-Bertrand (1973). The Language of Psycho-analysis, Donald Nicholson-Smith (trans.). New York: W.W. Norton and Company.

Lauretis Teresa (de) (1994). The Practice of Love: Lesbian Sexuality and Perverse Desire. Bloomington: Indiana University Press.

Levy Howard (1984). Chinese Footbinding: The History of a Curious Erotic Custom. Taibei: Nantian shuju.

Liu Lydia (2004). The Clash of Empires: The Invention of China in Modern World Making. Cambridge: Harvard University Press.

Mao shi zhengyi 毛詩正義 (1999). Beijing: Beijing daxue chubanshe. 
McMahon Keith (2005). Cultural Destiny and Polygynous Love in Zou Tao's Shanghai Dust. Chinese Literature: Essays, Articles, and Reviews, n 27: 117-135.

McMahon Keith (2007). Review of Dorothy Ko, Cinderella's Sisters. Nannü: Men, Women, and Gender in Early and Imperial China, $\mathrm{n}^{\circ} 9$ (2): 395-400.

McMahon Keith (2009). Polygamy and Sublime Passion: Sexuality in China on the Verge of Modernity. Honolulu: University of Hawaii Press.

Nobus Dany and Downing Lisa (eds) (2006). Perversion: Psychoanalytic Perpsectives/ Perspectives on Psychoanalysis. London: Karnac.

Steel Valerie (1996). Fetish: Fashion, Sex, and Power. New York and Oxford: Oxford University Press.

Sunü jing 素女經 (1976). In Ishimpō bōnai 医心方 房内, TAMBA Yasuyori 丹波康頼 (ed.). Tokyo: Edo bungakusen.

SUN YIRANG 孫詒讓 (1987). Zhouli zhengyi 周禮正義. Beijing: Zhonghua shuju.

Wu Renchen 吳任臣 (1983). Shiguo chunqiu 十國春秋. Beijing: Zhonghua shuju.

YU DA 俞達 (1990). Qinglou meng 青樓夢. Beijing: Beijing daxue chubanshe.

Ziтo Angela (2006). Bound to Be Represented: Theorizing/Fetishizing Footbinding. In Embodied Modernities : Corporeality, Representation, and Chinese Cultures, Fran Martin and Larissa HeInRICH (ed). Honolulu: University of Hawaii Press.

ŽıžEK Slavoj (1991). Looking Awry: An Introduction to Jacques Lacan through Popular Culture. Cambridge, Mass.: The MIT Press.

ŽžEK Slavoj (1993). Tarrying with the Negative: Kant, Hegel, and the Critique of Ideology. Durham: Duke University Press.

ŽIžEK Slavoj (1997a). Looking Awry: an Introduction to Jacques Lacan through Popular Culture. Cambridge: MIT Press.

ŽIžEK Slavoj (1997b). The Plague of Fantasies. London: Verso.

ŽıžEK Slavoj (ed.) (1998a). Cogito and the Unconscious. Durham: Duke University Press.

Žžž Slavoj (1998b). Four Discourses, Four Subjects. In Cogito and the Unconscious, Slavoj ŽıžEK (ed.). Durham: Duke University Press: 74-113.

ŽıžEK Slavoj (2000). The Fragile Absolute - or Why Is the Christian Legacy Worth Fighting For?. London: Verso.

ŽžEK Slavoj (2003). The Puppet and the Dwarf: the Perverse Core of Christianity. Cambridge, Mass.: The MIT Press.

Zuozhuan 左傳 (1999). In Chunqiu Zuozhuan zhengyi 春秋左傳正義. Beijing: Beijing daxue chubanshe. 


\section{GLOSSARY}

Ernü yingxiong zhuan 兒女英雄傳

fangzhong shu 房中術

Gu Hongming 顧鴻銘

Haishang hualie zhuan 海上花列傳

Honglou fumeng 紅樓復夢

Honglou meng 紅樓夢

Houfei zhuan 后妃傳

Huayue hen 花月痕

Jia Baoyu 賈寶玉

Jin Ping Mei 金瓶梅

Jiuwei gui 九尾龜

Lin Daiyu 林黛玉

Li Yu (Southern Tang Emperor) 李煜

$\mathrm{Li} \mathrm{Yu}$ 李漁

Ma馬

Mengyu 夢玉

Ming 明

Pinhua baojian 品花寶監

Qilou chongmeng 綺樓重夢

Qinglou meng 青樓夢

Qingwen 晴雯

shenghuan 生還

Shiji 史記

Sima Qian 司馬遷

Wang Mang 王莽

Xiren 襲人

Xue Baochai 薛寶釷

Yaoniang 首娘

Ying'er 鶯兒

yiyin 意淫

Zheng Xuan 鄭玄

Zijuan 紫鵑

Zuozhuan 左傳 
